\title{
THE USE DISCOVERY LEARNING METHOD IN TEACHING WRITING RECOUNT TEXT TO THE TENTH GRADE OF SMAN NGAMPRAH
}

\author{
Amel Purnamasari' ${ }^{1}$, Ningtyas Orilina Argawati ${ }^{2}$ \\ ${ }^{1}$ IKIP Siliwangi \\ ${ }^{2}$ IKIP Siliwangi \\ 1 amelpurnama@student.ikipsiliwangi.ac.id, ${ }^{2}$ tyas.orilina@gmail.com
}

\begin{abstract}
The purpose of this study was to determine the activities that occur during the teaching process of writing Recount Texts using the Discovery Learning method and to identify the benefits obtained by students from writing the Recount Text using the Discovery Learning method in the 2013 curriculum there is one learning model called Discovery Learning. Discovery Learning can help students to learn better because students can think critically and creative. This research is a qualitative descriptive study. The research respondents were English teachers and the tenth grade students of Ngamprah High School. Data obtained from observations and interviews. The results of the study revealed that the results of this study were positive. Students who are taught by using the method of Discovery Learning play an active role in the teaching and learning process. The composition of their writing also shows good results in terms of content, organization, Grammar,vocabulary, and mechanics. Therefore, it is recommended to apply this learning model to teach writing Recount Texts.
\end{abstract}

Keywords: Discovery Learning, Writing Skills, Recount Text

\section{INTRODUCTION}

In learning English, there are four skills to be mastered: Listening, Speaking, Reading, Writing. Studying also considers aspects of student success in learning English. According to Pincas (1982) "Writing is a way of communicating a message to a reader for a purpose" The Purpose of writing is to express ideas or feeling to the readers in order to impress the reader with the writer's thought (Nunan, 2003:88). Scott (1990: 69) as cited in Yulianti \& Parmawati (2019) defines Writing is an interesting activity, it can give students some advantages although basically there are difficulties in writing but it is still a useful, essential, integral and enjoyable part of the foreign language lesson.

As a basic skill in English language, writing skill could not be separated from educational sector. The main reason, English learners at school must be able to express their ideas or feeling in spoken or written forms effectively. However, writing is regrded as the most difficult skill to be taught in English subject (Apsari, 2017).In addition, students' motivation to write is low. Some students are very uncomfortable and are reluctant to write for several reasons. The main reason is because they think that nothing can be written and they don't know what to write because of a lack of vocabulary, grammar, and sentence management.

\section{Writing skills}

We know that English not our native language, as a fact that mastery is not easy. The components and skill of English are important for language learners especially the tenth grade. Brown (2007) 
Composition Profile Criteria were selected to evaluate the student's writing result. The Profile was divided into five major writing components: Content, organization, Grammar, vocabulary, and mechanics that can give the effect to the English-language skills; such as listening, reading, speaking and writing.

Blanchard and Root (2003:41), there are two steps in writing process they are prewriting, and writing. All writing steps are important to make writing be better and systematic.

\section{Prewriting}

At this stage students are required to prepare the writing process by training their brains by collecting ideas so that it is easy during the writing process.

2. Writing

The next step is the writing process. At this stage students begin to pour their ideas into writing with the results of gathering their ideas at the time of pre-writing.

\section{Recount Text}

Recount is a texs that retell events or experience in the past. Recount text has a generic structure consists of orientation, a series of events with sequential sentences, and reorientation that "complete" the sequence of events or conclusion from the whole story.

This is a point when writers try to create a piece of a Recount Text. Anderson (1997: 53) stated that a Recount Text has three main parts: 1) Orientation; Introducing the participants, place and time. 2).Events: Retell the story or experience in the past with sequential, and 3) e-Orientation: It is optional. Conclude all the contents of the story.

\section{METHOD}

This research was conducted at SMAN Ngamprah and the subject was class tenth grade students consisting of 34 students. This study chose class tenth grade students because the researchers assessed those at this level must be able to write Recount Text in the correct context.

The method used in this research is Discovery Learning. Discovery learning is a learning model which let the students to find out about new concept that they do not know before. This learning model may be useful for students because it changes passive learning process to be more active and creative. It also changes the learning process which was teacher oriented to become student oriented. So, instead of get the information from the teacher, the student are expected to gather the information by themselves.

Discovery Learning is learning by discovering information just like inquiry-based learning. It requires active participation in scientific investigation. Bruner (1961) stated that "Discovery Learning can be defined as the learning that takes place when the student is not presented with the subject matter in the final form, but rather is required to organize it himself."

This aim of this research is The Use Discovery Learning Method in Teaching Writing Recount Text to The Tenth Grade of SMAN Ngamprah. Following the procedure in Discovery Learning: 
1. Stimulation. The teacher starts the activity learning by asking questions, encouraging reading books, and other learning activities that lead to the preparation of problem solving.

2. Problem Statement . After stimulation, the next step is the teacher gives students to identify as many agendas as possible that are relevant to the subject matter, then one of them is chosen and formulated in a hypothetical form, the problem chosen must then be formulated in the form of a question, or hypothesis, which is a statement as a temporary answer to the question asked.

3. Data Collection. When exploration takes place the teacher providing opportunity for students to gather as much information as is relevant to prove whether or not the hypothesis. This stage serves to answer the question or prove whether or not the hypothesis.

4. Data Processing. The teacher gives guidance at the time of students do data processing.

5. Verification. The teacher providing opportunity for students to find a concept, theory, rules or understanding through the examples that he encountered in his life.

6. Generalization. The teacher draws conclusions of the material applied during the learning process.

For data collection, researchers used qualitative descriptive. Qualitative descriptive relating to events and changes that occur during class activities. Researchers collected qualitative descriptive using interviews.

Table 1. Rubric of writing by Brown (2007)

\begin{tabular}{|c|c|c|c|}
\hline Aspect & Score & Performance Description & Weighting \\
\hline \multirow{4}{*}{$\begin{array}{l}\text { Content } \\
\text { (C) } \\
30 \% \\
\text { - Topic } \\
\text { - Details }\end{array}$} & 4 & $\begin{array}{l}\text { The topic is complete and clear and the details } \\
\text { are relating to the topic }\end{array}$ & \multirow{4}{*}{ 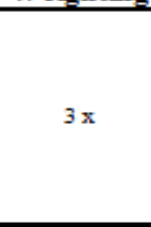 } \\
\hline & 3 & $\begin{array}{l}\text { The topic is complete and clear but the details } \\
\text { are almost relating to the topic. }\end{array}$ & \\
\hline & 2 & $\begin{array}{l}\text { The topic is complete and clear but the details } \\
\text { are not relating to the topic. }\end{array}$ & \\
\hline & 1 & $\begin{array}{l}\text { The topic is not clear and the details are not } \\
\text { relating to the topic. }\end{array}$ & \\
\hline \multirow{4}{*}{$\begin{array}{c}\text { Organization } \\
(\mathrm{O}) \\
20 \% \\
\text { - Identification } \\
\text { - Description }\end{array}$} & 4 & $\begin{array}{l}\text { Identification is complete and descriptions are } \\
\text { arr anged with proper connectives }\end{array}$ & \multirow{4}{*}{$2 \mathrm{x}$} \\
\hline & 3 & $\begin{array}{l}\text { Identification is almost complete and } \\
\text { descrip tions are amanged with almost proper } \\
\text { connectives }\end{array}$ & \\
\hline & 2 & $\begin{array}{l}\text { Identification is not complete and descriptions } \\
\text { are arranged with few misuse of connectives }\end{array}$ & \\
\hline & 1 & $\begin{array}{l}\text { Identification is not complete and descriptions } \\
\text { are arranged with misuse of comectives }\end{array}$ & \\
\hline \multirow{4}{*}{$\begin{array}{c}\text { Grammar } \\
(\mathrm{G}) \\
20 \% \\
\text { - Use present } \\
\text { tense } \\
\text { - Agreement }\end{array}$} & 4 & $\begin{array}{l}\text { Very few grammatical or agreement } \\
\text { inaccuracies }\end{array}$ & \multirow{4}{*}{$2 \mathrm{x}$} \\
\hline & 3 & $\begin{array}{l}\text { Few gramma tical or agreement inaccuracies but } \\
\text { not affect on meaning }\end{array}$ & \\
\hline & 2 & $\begin{array}{l}\text { Numerous grammatical or agreement } \\
\text { inaccuracies }\end{array}$ & \\
\hline & 1 & $\begin{array}{l}\text { Frequent grammatical or agreement } \\
\text { inaccuracies }\end{array}$ & \\
\hline \multirow{4}{*}{$\begin{array}{c}\text { Vocabulary (V) } \\
15 \%\end{array}$} & 4 & Effective choice of words and word forms & \multirow{4}{*}{$1.5 \mathrm{x}$} \\
\hline & 3 & $\begin{array}{l}\text { Few misuse of voc abular ies, word forms, but } \\
\text { not change the meaning }\end{array}$ & \\
\hline & 2 & Limited range confusing words and word form & \\
\hline & 1 & $\begin{array}{l}\text { Very poor knowledge of words, word forms, } \\
\text { and not understand able }\end{array}$ & \\
\hline \multirow{4}{*}{$\begin{array}{c}\text { Mechanics (M) } \\
15 \% \\
\text { - Spelling } \\
\text { - Punctuation } \\
\text { - Capitalization }\end{array}$} & 4 & $\begin{array}{l}\text { It uses correct spelling, punctua tion, and } \\
\text { capitalization }\end{array}$ & \multirow{4}{*}{$1.5 \mathrm{x}$} \\
\hline & 3 & $\begin{array}{l}\text { It has occ asional err ors of spetling, punctuation, } \\
\text { and capitalization }\end{array}$ & \\
\hline & 2 & $\begin{array}{l}\text { It has frequent errors of spelling, punctuation, } \\
\text { and capitalization }\end{array}$ & \\
\hline & 1 & $\begin{array}{l}\text { It is dominated by err ors of spetling, } \\
\text { punc tuation, and capitalization }\end{array}$ & \\
\hline
\end{tabular}




\section{RESULTS AND DISCUSSION}

\section{Results}

In this section, the researchers presented the results of using Discovery Learning methods to improve the ability to writing Recount Text students in class X of Ngamprah High School. This research was conducted at five meetings. Each teacher meeting follows procedure of Discovery Learning.

The first meeting, in stimulation, the teacher displays the understanding of the Recount Text, examples and their use through power points then the students are asked to listen and then asks them to read the text about B.J Habibie's Recount Text.

The second meeting, after giving stimulation, the teacher asks students to identify the goals and details of the structure of the reading that has been read by completing the available tables and then students gather information to answer the questions that have been identified.

The third meeting, the teacher guides students to recognize sentences in simple past tense to be applied in the Recount Text, then students discuss the results of their observations and verification their observations with data or theories in the source book they are looking for.

At the fourth meeting, the teacher reviewed and generalization what had been learned about the Recount Text.

The fifth meeting, the teacher does a post test in order to know the ability of students in remembering and capturing Recount Text lessons using Dicovery Learning methods

This section shows the results posttest of learning to write Recount Text using the Discovery Learning method provided as an instrument. The results of the post test can be seen in the table below:

Table 2. The Result of Posttest

\begin{tabular}{ccc}
\hline No & Name & Posttest Score \\
\hline $\mathbf{1}$ & Student 1 & 80 \\
\hline $\mathbf{2}$ & Student 2 & 82 \\
\hline $\mathbf{3}$ & Student 3 & 82 \\
\hline $\mathbf{4}$ & Student 4 & 80 \\
\hline $\mathbf{5}$ & Student 5 & 80 \\
\hline $\mathbf{6}$ & Student 6 & 83 \\
\hline $\mathbf{7}$ & Student 7 & 80 \\
\hline $\mathbf{8}$ & Student 8 & 80 \\
\hline $\mathbf{9}$ & Student 9 & 82 \\
\hline $\mathbf{1 0}$ & Student 10 & 80 \\
\hline $\mathbf{1 1}$ & Student 11 & 82 \\
\hline $\mathbf{1 2}$ & Student 12 & 80 \\
\hline $\mathbf{1 3}$ & Student 13 & 75 \\
\hline
\end{tabular}




\begin{tabular}{lll}
\hline $\mathbf{1 4}$ & Student 14 & 82 \\
\hline $\mathbf{1 5}$ & Student 15 & 80 \\
\hline $\mathbf{1 6}$ & Student 16 & 83 \\
\hline $\mathbf{1 7}$ & Student 17 & 70 \\
\hline $\mathbf{1 8}$ & Student 18 & 80 \\
\hline $\mathbf{1 9}$ & Student 19 & 80 \\
\hline $\mathbf{2 0}$ & Student 20 & 75 \\
\hline $\mathbf{2 1}$ & Student 21 & 82 \\
\hline $\mathbf{2 2}$ & Student 22 & 80 \\
\hline $\mathbf{2 3}$ & Student 23 & 82 \\
\hline $\mathbf{2 4}$ & Student 24 & 75 \\
\hline $\mathbf{2 5}$ & Student 25 & 82 \\
\hline $\mathbf{2 6}$ & Student 26 & 80 \\
\hline $\mathbf{2 7}$ & Student 27 & 77 \\
\hline $\mathbf{2 8}$ & Student 28 & 80 \\
\hline $\mathbf{2 9}$ & Student 29 & 83 \\
\hline $\mathbf{3 0}$ & Student 30 & 80 \\
\hline $\mathbf{3 1}$ & Student 31 & 82 \\
\hline $\mathbf{3 2}$ & Student 32 & 75 \\
\hline $\mathbf{3 3}$ & Student 33 & 82 \\
\hline $\mathbf{3 4}$ & Student 34 & 75 \\
\hline
\end{tabular}

The result of teaching learning writing using Discovery Learning method showed the significant improvement from five meeting. Post test result can be seen from the scores obtained by students after five meetings, calculated from Brown (2007) because in the related aspects there are each score for example content, organization, grammar, vocabulary and mechanics, the results are seen of the words in the text are longer and more detailed, and their scores are higher and reach a minimum score with an average score of 80 . But there are students who have low grades, especially in grammar. and In this aspect, there are some students still wrong in the sentence structure but they are better than before.

\section{Discussion}

From the above results, researchers can discuss teaching and learning English using Discovery Learning can significantly improve students' recount text writing. This method shows a positive increase in students' writing skills, before the Discovery Learning method is carried out, students have difficulty in finding vocabulary and producing words, phrases or sentences to express their ideas, using grammar in well-formed sentences, and increase their focus and motivation. Through Discovery learning the average value of students becomes 80 .

To make sure this research is valid, the researcher also confirms by referring readers to read other similar journals. Here, researchers found a relative study of the use of Discovery Learning methods conducted by Sobari \& Husnussalam (2019) entitled The Use of Discovery Learning 
Method to Improve Students' Writing Descriptive Text. They claim that teaching by writing using the Discovery Learning method can improve the ability to write descriptive texts in tenth grade students at MA Nurul Hidayah Batujajar.

\section{CONCLUSION}

According to the results of the study, the researchers drew the conclusion that Discovery Learning is considered as an effective learning model for improving writing Recount Texts using Discovery Learning methods for tenth grade students. It was proven by the students who actively answered the questions given by the teacher which was about the information of the topic. In other words, the students tried to find the information by themselves so that they could answer the questions given by the teacher. It implied that the students played an active role in the teaching and learning process which was in line with the purpose of this learning model.

Moreover, after the implementation, the development of student writing shows good results. This can be seen from the students' writing compositions which were mostly labelled as "good to average" level. They wrote recount text with good content and organization, rich vocabularies, grammar and mechanics. Thus, by applying Discovery Learning, the students can develop their potentiality in writing Recount Text.

\section{ACKNOWLEDGMENTS}

Alhamdulillah, thanks to Allah grace this journal can be completed. I would like to express my deepest gratitude to my beloved parents, dad and mom, brother, sister for their love, motivation, prayer, material support and those who have provided assistance in the process. They are:

1. Ningtyas Orilina Argawati, M.Pd., as the journal advisor.

2. Syaepudin, S. Pd., as the principle of SMAN Ngamprah.

3. Dra. Hj. Etty Hatijah, S. Pd., as English teacher of SMAN Ngamprah.

4. My best friends and all 2016 students in English Education Department of IKIP Siliwangi, especially Syarah Syahidah Rusmana, Deasy Putri, Nita Fauziah, Diah Ayu Tristianty, and Ramdita Wulandari.

\section{REFERENCES}

Apsari, Y. (2017). The Use Of Picture Series In Teaching Writing Recount Text. Eltin Journal, Journal Of English Language Teaching In Indonesia, 5(2), 51-56.

Astin, U. (2019). Linguists : Journal Of Linguistics And Language Teaching. 5(1), 46-55.

Blanchard, K. (N.D.). Karen Blanchard Christine Root.

David, N. (2003). Practical English Language Teaching (1st Ed, P. 342). New York, N.Y.: Mcgraw-Hill/Contemporary, [2003].

H. Douglas, B. (2004). Language Assessment (Principles And Classroom Practices) (Jane Townsend (Ed.)). Longman.

Islami, N. M., \& Aswandi, H. (2017). The Implementation Of Discovery Learning To Teach Writing Recount Text To Tenth Graders. Retain, 5(2), 73-81.

Kusumawardhani, A. D., Mulya, D., \& Faizah, A. (2019). Empowering Students' Creativity And Critical Thinking Through Discovery Learning-Based Writing Assessment. Linguists: Journal Of Linguistics And Language Teaching, 5(1), 1. 
Lestari, W. I., Mawaddah, U., \& Kareviati, E. (2019). The Influence Of Discovery Learning And Snowball Throwing Method In Improving Writing Skills Of High School Students. Project (Professional Journal Of English Education), 2(3), 332.

Pincas, A. (1982). Teaching English Writing (H. F. Roger (Ed.)). The Macmillan Press Limited.

Sobari, M. R., \& Husnussalam, H. (2019). The Use Of Discovery Learning Method To Improve Students 'Writing Descriptive Text. 2(2), 133-139.

Suryaman, Y. (2019). Improving Students' Ability In Writing Recount Text Using Diary At One Of Junior High School In Campaka - Cianjur. Project (Professional Journal Of English Education), 1(2), 43.

Yulianti, S., Nuraeni, S., \& Parmawati, A. (2019). Improving Students'writing Skill Using Brainswriting Strategy. Project (Professional Journal Of English Education), 2(5), 714721. 